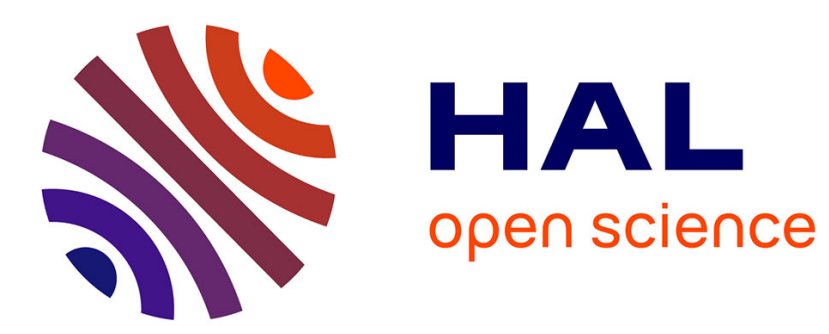

\title{
A Testing Technique of Confined Compression for Concrete at High Rates of Strain
}

\author{
Pascal Forquin, G. Gary, Fabrice Gatuingt
}

\section{To cite this version:}

Pascal Forquin, G. Gary, Fabrice Gatuingt. A Testing Technique of Confined Compression for Concrete at High Rates of Strain. 13th International Conference on Experimental Mechanics - ICEM13, Jul 2013, Alexandroupolis, Greece. hal-01625162

\section{HAL Id: hal-01625162 \\ https://hal.science/hal-01625162}

Submitted on 27 Oct 2017

HAL is a multi-disciplinary open access archive for the deposit and dissemination of scientific research documents, whether they are published or not. The documents may come from teaching and research institutions in France or abroad, or from public or private research centers.
L'archive ouverte pluridisciplinaire HAL, est destinée au dépôt et à la diffusion de documents scientifiques de niveau recherche, publiés ou non, émanant des établissements d'enseignement et de recherche français ou étrangers, des laboratoires publics ou privés. 


\title{
A TESTING TECHNIQUE OF CONFINED COMPRESSION FOR CONCRETE AT HIGH RATES OF STRAIN
}

\author{
P. Forquin ${ }^{1}$, G. Gary ${ }^{2}$ \& F. Gatuingt ${ }^{3}$ \\ ${ }^{1}$ Laboratoire de Physique et de Mécanique des matériaux, Université Paul Verlaine de Metz, 57045 \\ Metz, France, pascal.forquin@univ-metz.fr \\ ${ }^{2}$ Laboratoire de Mécanique des Solides, Ecole Polytechnique, 91128 Palaiseau, France, \\ Gary@Ims.polytechnique.fr \\ ${ }^{3}$ Laboratoire de Mécanique et Technologie, E.N.S. de Cachan, 61 av. du Pt Wilson, 94235 Cachan, \\ France, Fabrice.Gatuingt@Imt.ens-cachan.fr
}

\begin{abstract}
In order to characterise the behaviour of concrete under high pressures and high strain-rates, dynamic 1D-strain compression tests were performed. A cylindrical specimen is embedded in a steel confinement ring and compressed between 2 cylindrical plugs with a SHPB (Split Hopkinson Pressure Bars) device. Moreover, a new method was used to process the experimental data. It is based on numerical simulations of the cell loaded by an internal pressure that allow to build a relation between the pressure applied by the concrete to the inner surface of the cell and the external hoop strain measured by gauges. Stresses and strains in the specimen are computed at any loading time and the evolution of the deviatoric stress versus the pressure (deviatoric behaviour) and of the pressure versus volumetric strain (spherical behaviour) is deduced. The method is validated by several numerical simulations of the test involving different friction coefficients between the cell and the specimen.
\end{abstract}

Three 1D-strain compression tests were performed and processed with the MB50 high-performance concrete. They showed that the deviatoric and spherical behaviours are almost independent of the strain rate in the observed range of strain rates (80$\left.221 \mathrm{~s}^{-1}\right)$. The deviatoric strength is seen to increase regularly with the hydrostatic pressure. The spherical behaviour indicates a fairly constant dynamic modulus of compressibility (around 5 to $6 \mathrm{GPa}$ ) up to a pressure of $900 \mathrm{MPa}$.

\section{Introduction}

The compaction of concrete associated with a volume decrease over $10 \%$ occurs under high pressures. Such situations are found in military applications (blast loading, penetrating projectile) or in studies for the safety of buildings (power plants) regarding an accidental internal loading or external loading (plane crash). In such situations, a compressive loading, with high pressures (up to $1000 \mathrm{MPa}$ ) and high strain-rates (up to some hundreds of $\mathrm{s}^{-1}$ ), is produced.

The use of the compressive Split Hopkinson Pressure Bar (SHPB) to determine the rate sensitivity of concrete can be found in recent works [1-5]. However, the test analysis must consider both material and structural aspects. For example, the increase of the stress with the strain rate can be due to the radial confinement induced by inertial effect and/or by the intrinsic rate sensitivity of the material. Indeed, for a material with a non-zero Poisson's ratio, the lateral expansion associated with the compression is restrained by inertia effects [6-9]. As rock-like materials are very sensitive to the lateral pressure when they are axially loaded, they can show artificial apparent strain-rate sensitivity. In the present case, the confinement cell considerably reduces the radial displacement and the radial pressure due to inertia is not acting. Dynamic axial compression testing with lateral pressure is not so common. For lower lateral pressures, experimental data are obtained using a SHPB axial loading system combined with a pressure cell $[5,10,11,12]$. This technique does not allow for the high pressures required for compaction.

A new testing device of confined compression has been designed and used in the case of quasi-static loading in [13], involving axial and lateral stresses in the range of expected dynamic values. In the present work, an analogous technique is used in the 
dynamic range using a SHPB to produce an axial loading and to measure axial forces and displacements. First, the principle of the 1D-strain compression test is presented. The methodology of processing the data is detailed next. It is validated by means of several numerical simulations for which the methodology of processing the experimental data is employed. In particular, influence of friction between the specimen and the cell is pointed out. Finally, the methodology is used to analyse three 1D strain compression tests performed by Split Hopkinson Pressure Bars.

\section{Principle of quasi-oedometric compression tests}

The principle of the test is described in Figure 1. A cylindrical specimen (diameter: $30 \mathrm{~mm}$, length: $40 \mathrm{~mm}$ ) is embedded in an instrumented steel confinement ring (Fig. 1b, outer diameter: $65 \mathrm{~mm}$, length: $45 \mathrm{~mm}$ ) and is compressed between 2 cylindrical plugs (Fig. 1a). A gap, about $0.2 \mathrm{~mm}$ thick, is left between the concrete specimen and the ring. It is filled with an epoxidic resin, coated with Teflon. This material is highly uncompressible and it does not reduce the confinement pressure. It also has a weak shear behaviour allowing for easier relative displacements between the ring and the specimen. Three hoop strain gauges were glued on the external surface of the metallic ring (Fig. 1b). From the corresponding measurements, it is expected to deduce the radial stress and strain within the specimen. One gauge is located in the middle of the ring $\left(n^{\circ} 2\right)$ and the two others $\left(n^{\circ} 1\right.$ and 3) are located at a distance from the middle equal to $3 / 4$ of the half-length of the ring (Fig. $1 \mathrm{~b})$. Three axial gauges $\left(n^{\circ} 4,5\right.$, 6 ) are located on the same axial planes (Fig. 1b). From their measurements, it is expected to compute the barrelling of the ring.

A SHPB is used to produce a dynamic axial loading (Fig. 1c). It is composed of the long input (or incident) and output (or transmitter) bars with a short specimen placed between them. With the impact of a projectile (or striker) at the free end of the input bar, a compressive longitudinal "incident" wave $\varepsilon_{I}(\mathrm{t})$ is created in the input bar. Once the incident wave reaches the interface specimen-bar, a reflected pulse $\varepsilon_{R}(\mathrm{t})$ in the input bar and a transmitted pulse $\varepsilon_{T}(\mathrm{t})$ in the output bar are developed. With the gauges that are glued on the input and output bars (A and B, Fig. 1c), these three basic waves are recorded. Their processing allows for the knowledge of forces and particle velocities at both faces of the specimen [14]. The cell and its plugs are inserted between the two Hopkinson bars. The loading produces a compression of the concrete and a subsequent increase of the internal pressure supported by the cylindrical cell. The signals recorded with the gauges glued on the cell give information on its response under concrete pressure.

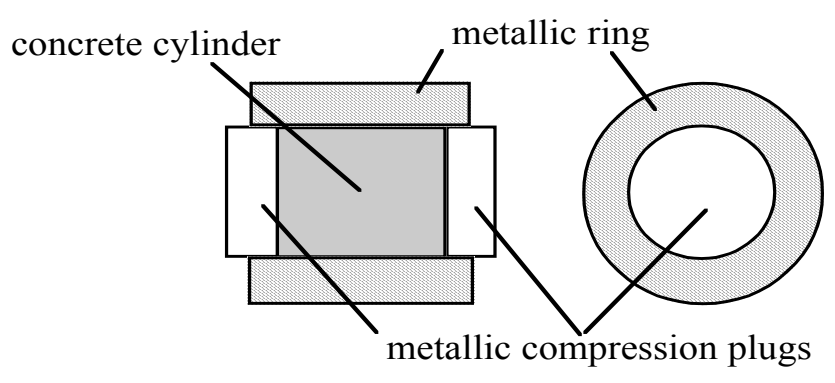

FIGURE 1a. The concrete specimen embedded in the steel ring

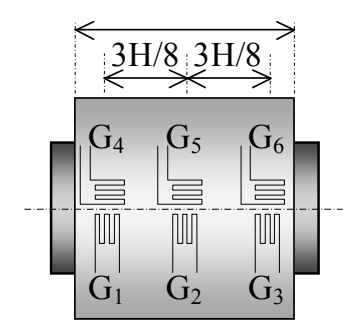

Fig.1b Position of the 6 gauges

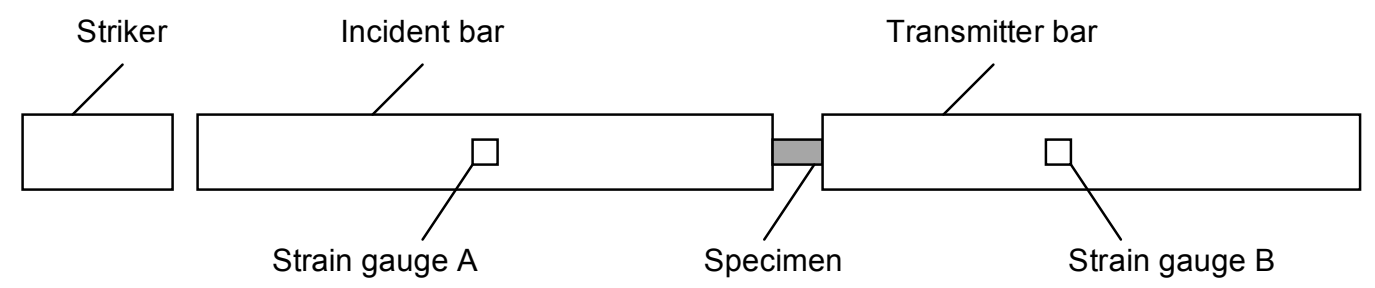

FIGURE 1c. The SHPB device

FIGURE 1. 1D-strain compression device.

The selected high strength concrete "MB50" has already been extensively studied [15-18]. The specimens to be tested were machined in a concrete block after being dried (40 days) to prevent the effects of drying shrinkage of the concrete. The composition and the mean mechanical properties of MB50 are detailed in Table 1. 
TABLE 1. Composition and mechanical properties of MB50 concrete.

\begin{tabular}{|c|c|}
\hline \multicolumn{2}{|c|}{ Composition of MB50 [15] } \\
\hline Sand $\left(\mathrm{kg} / \mathrm{m}^{3}\right)$ & 1783 \\
\hline Cement $\left(\mathrm{kg} / \mathrm{m}^{3}\right)$ & 400 \\
\hline Water $\left(\mathrm{kg} / \mathrm{m}^{3}\right)$ & 200 \\
\hline Admixture $\left(\mathrm{kg} / \mathrm{m}^{3}\right)$ & 12 \\
\hline Water/Cement & 0.5 \\
\hline Max grain size (mm) & 5 \\
\hline \multicolumn{2}{|c|}{ Mechanical properties of MB50 [15] } \\
\hline Compressive strength (MPa) & 70 \\
\hline Tensile strength (MPa) & 3.0 \\
\hline
\end{tabular}

\section{Methodology of processing of experimental data}

First, it is studied how the pressure applied by the concrete to the inner surface of the cell is related to the hoop strain measured at its outer surface. To do so, numerical simulations of the cell loaded by an internal pressure were carried out using the finite elements computer code Abaqus-Standard [19]. A similar approach was successfully applied before to a smaller steel ring which elastic limit was lower [20]. The computations showed a noticeable barrelling of the cell. In the present case, the geometry of the cell is as described before (outer diameter equal to $65 \mathrm{~mm}$, inner diameter equal to $30 \mathrm{~mm}$ and $45 \mathrm{~mm}$ height). Two numerical simulations were carried out to take account of the change in length of the specimen during the test. In both cases, a continuously increasing radial compressive stress is applied on the inner surface (cylindrical). In the first case, this pressure is applied to a central part of the cell $40 \mathrm{~mm}$ long (smaller than the cell length), equal to the initial length of the sample. In the second numerical simulation, the pressure is applied to a shorter central part $34 \mathrm{~mm}$ long (equal to the specimen length at the end of the test in the case of a nominal axial strain equal to -15\%). The two curves (internal-radial-stress versus external-hoop-strain) are plotted in Figure 2. From both simulations, it is shown that the cell remains in the elastic range when the internal pressure is lower than approximately $300 \mathrm{MPa}$, and the external hoop strain is approximately lower than $0.1 \%$. Anyway, the post-processing of the data proposed below that is based on the interpolation between above loadings is still possible when the cell is plastically loaded. In such a case, the same cell could not be used more than once. From curves of Figure 2, the relation between the measured outer hoop strain $\varepsilon_{\theta \theta}{ }^{(z=0 \text {, ext) }}$ and the radial inner stress $\bar{\sigma}_{\text {radial }}^{\text {(int) }}$ is built according to equation [1].

$$
-\bar{\sigma}_{\text {radial }}^{\text {(int) }}\left(\bar{\varepsilon}_{\text {axial }}, \varepsilon_{\theta \theta}^{(z=0, e x t)}\right)=\left(1-\frac{\bar{\varepsilon}_{\text {axial }}}{\varepsilon_{B}}\right) \sigma_{A}\left(\varepsilon_{\theta \theta}^{(z=0, e x t)}\right)+\left(\frac{\bar{\varepsilon}_{\text {axial }}}{\varepsilon_{B}}\right) \sigma_{B}\left(\varepsilon_{\theta \theta}^{(z=0, e x t)}\right)
$$

where $\sigma_{A}$ and $\sigma_{B}$ are the functions identified from Figure 2 and $\varepsilon_{B}$ is a reference strain equal to 0.15 . It will be assumed in the following that the radial stress is homogeneous in the sample and consequently is equal to the radial stress applied by the sample to the cell $\left(\bar{\sigma}_{\text {radial }}^{\text {(int) }}=\bar{\sigma}_{r r}^{S}\right.$ ). Moreover, in the above simulations, the strains (and stresses) can be calculated at any point in the cell. Figure $2 \mathrm{~b}$ shows the evolution of the inner hoop strain at points $z=0$ (the axial symmetry plane) and $z=h_{0} / 2$ (the initial specimen ends) for both simulated loading cases $(A$ and $B)$ as a function of the external hoop strain $\left(\varepsilon_{\theta \theta}{ }^{(z=0, \text { ext })}\right)$. It appears (as expected) that the barrelling effect is stronger in the case $\mathrm{B}\left(h_{\text {press }}=34 \mathrm{~mm}\right)$ than in the case $\mathrm{A}\left(h_{\text {press }}=40 \mathrm{~mm}\right)$. It is then possible to compute the average inner hoop strain along the specimen height (between $z=0$ to $z=h_{\text {specimen }} / 2$ ) knowing the outer hoop strain measured on the cell and the axial strain of the specimen. Then, knowing the average radial strain of the specimen, the average specimen area is obtained:

$$
\overline{A_{s}}=A_{0}\left(1+f\left(\varepsilon_{\theta \theta}^{(z=0, e x t)}\right)\right)
$$

The average axial stress is then:

$$
\bar{\sigma}_{Z Z}^{S}=\frac{F_{\text {axial }}}{\overline{A_{S}}}
$$

where $F_{\text {axial }}$ is the force deduced from SHPB measurements. 

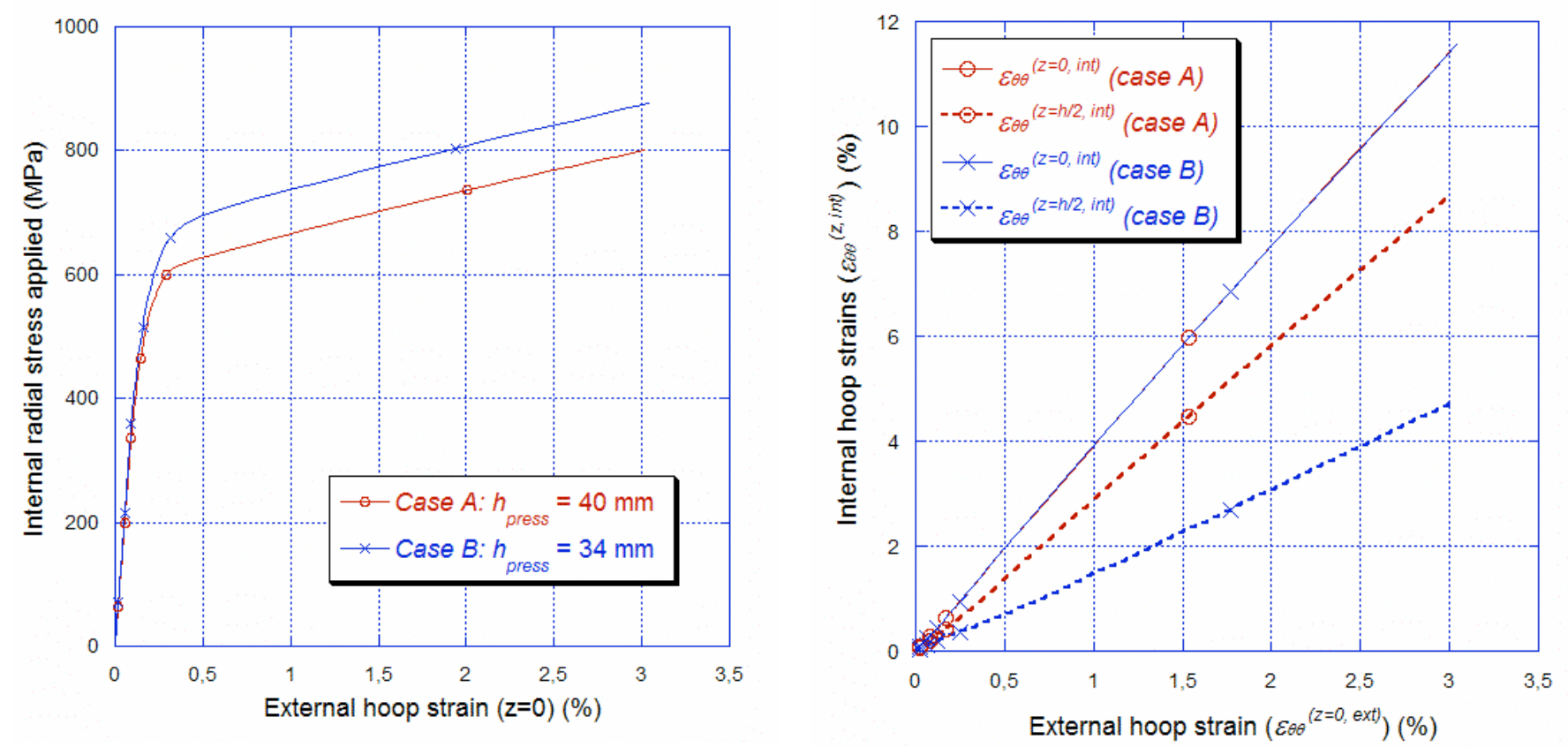

FIGURE 2a, left. Internal pressure versus external hoop strain $(z=0)$

FIGURE $2 b$, right. Internal hoop strains $\left(z=0, h_{0} / 2\right)$ versus external hoop strain $(z=0)$

FIGURE 2. Numerical simulation of a cell internally loaded by a pressure applied to its central part (A: $40 \mathrm{~mm}$, B: $34 \mathrm{~mm})$.

The radial stress being known, the average deviatoric stress is:

$$
\bar{\sigma}_{\text {deviatoric }}^{S}=\left|\bar{\sigma}_{z z}^{S}-\bar{\sigma}_{r r}^{S}\right|
$$

The average hydrostatic pressure and the volumetric strain are given by the formulas:

$$
\begin{gathered}
\bar{P}_{\text {hydrostatic }}^{S}=-\frac{1}{3}\left(\bar{\sigma}_{z z}^{S}+2 \bar{\sigma}_{r r}^{S}\right), \\
\bar{\varepsilon}_{\text {volumic }}^{S}=\left(1+\bar{\varepsilon}_{\text {axial }}\right)\left(1+\bar{\varepsilon}_{r r}^{S}\right)^{2}-1 .
\end{gathered}
$$

Knowing the axial stress and the internal pressure, the deviatoric behaviour (i.e. the supposed evolution of the deviatoric stress versus the hydrostatic pressure) and spherical behaviour (variation of the volumetric strain versus the hydrostatic pressure) can be calculated.

\section{Numerical validation of the method}

In order to check the validity of the proposed method used to process the experimental data, artificial experimental tests are built with numerical simulations. These simulations use the concrete plasticity model (the KST model, see underneath). Meanwhile, the main hypothesis introduced in previous chapter will be justified (influence of the specimen shortening, of the cell inflation, homogeneity of the radial stress field).

\section{The Krieg, Swenson and Taylor (KST) model}

The model of Krieg, Swenson and Taylor [21, 22] is relatively simple and was implemented as a Fortran procedure (Vumat) in the Abaqus-Explicit code [23]. It describes the spherical behaviour by a compaction law linking the volumetric strain to the hydrostatic pressure (Table 2). The final constant compressibility modulus $K_{f}$ (Table 2$)$ is used for highest pressures $(P>1$ $\mathrm{GPa}$ ). Moreover, the Von Mises equivalent stress $\sigma_{e q}$ cannot exceed a function of the hydrostatic pressure P (equation 7). 


$$
\sigma_{e q}=\min _{P}\left(\sqrt{a_{0}+a_{1} P+a_{2} P^{2}}, \sigma_{\text {mises }}^{\max }\right)
$$

The coefficients $\left(a_{0}, a_{1}, a_{2}\right)$ used in the subsequent simulations where identified from triaxial compression tests carried out under different confining pressures with MB50 concrete [18]. These coefficients are indicated in Table 2.

TABLE 2. Parameters of the Krieg, Swenson and Taylor model used in the numerical simulations

\begin{tabular}{|l|c|c|}
\hline Density, elastic constants: & $\rho, E, v$ & $2.386,36 \mathrm{GPa}, 0.2$ \\
\hline First point of the compaction curve: & $\varepsilon_{v}^{(l)}, P^{(1)}$ & $-0.003,60 \mathrm{MPa}$ \\
Second point of the compaction curve: & $\varepsilon_{v}^{(2)}, P^{(2)}$ & $-0.2,1 \mathrm{GPa}$ \\
Initial and final bulk moduli: & $K_{i}, K_{f}$ & $20 \mathrm{GPa}, 20 \mathrm{GPa}$ \\
\hline Coefficients of the elliptic equation: & $a_{0}, a_{l}, a_{2}$ & $1800 \mathrm{MPa}^{2}, 240 \mathrm{MPa}, 0.6$ \\
Maximum equivalent stress: & $\sigma_{\text {mises }}^{\max }$ & $550 \mathrm{MPa}$ \\
\hline
\end{tabular}

\section{Numerical simulations of one 1D-strain compression test}

Half of the cylindrical concrete specimen is compressed between a cylindrical steel compression plug and the axial symmetry plane $(z=0$, Figure 3$)$. An axial velocity is imposed on the upper surface of the compression plug. Under-integrated axisymmetric finite elements CAX4R are used. The numerical simulation of Figure 3 uses parameters illustrated in Table 2. Figures $3 \mathrm{a}$ and $3 \mathrm{~b}$ show the iso-contours of the hoop and axial strains for a nominal axial strain nearly equal to $-20 \%$. One can notice the continuity of the hoop strain field between the sample and the cell. The axial strain and the stress fields are also almost homogeneous in the sample $\left(-1100 \mathrm{MPa}>\sigma_{\mathrm{zz}}>-1400 \mathrm{MPa}\right)$. A concentration of stresses is observed near the contact between the plug and the sample. It is due to the smaller diameter of the plug (Figure 3d). Moreover, it is observed that the radial stress is homogeneous in the sample and is constant at the contact between the plug and the sample (Figure $3 \mathrm{c}$ ). This point justifies the assumptions used for the numerical simulations involving the cell only (Figure 2).

FIGURE 3a. Hoop strain $\varepsilon_{\theta \theta}$

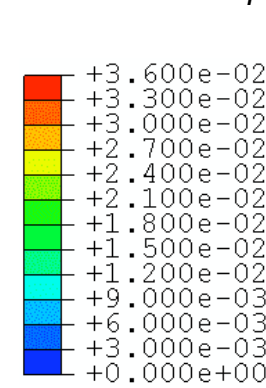

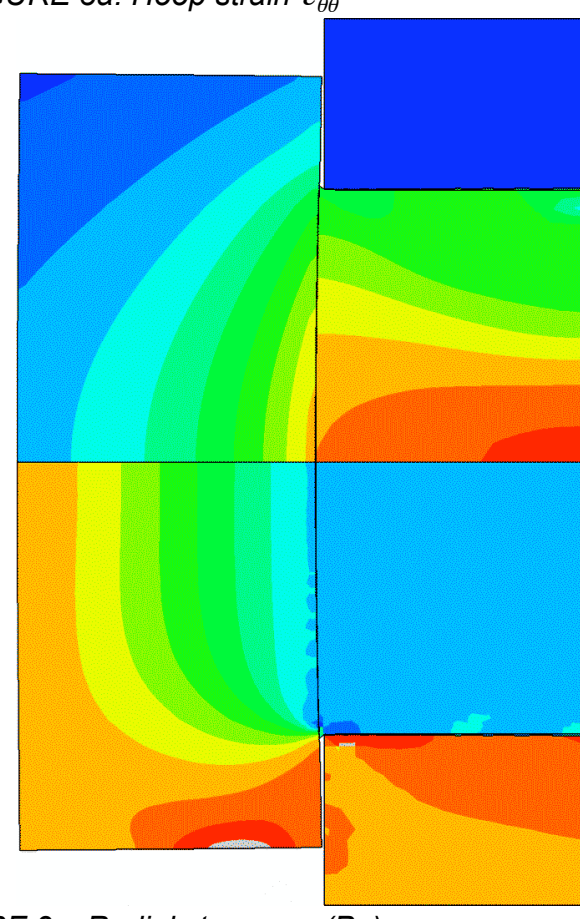

$(\mathrm{Pa})$
FIGURE 3b. Axial strain $\varepsilon_{z z}$
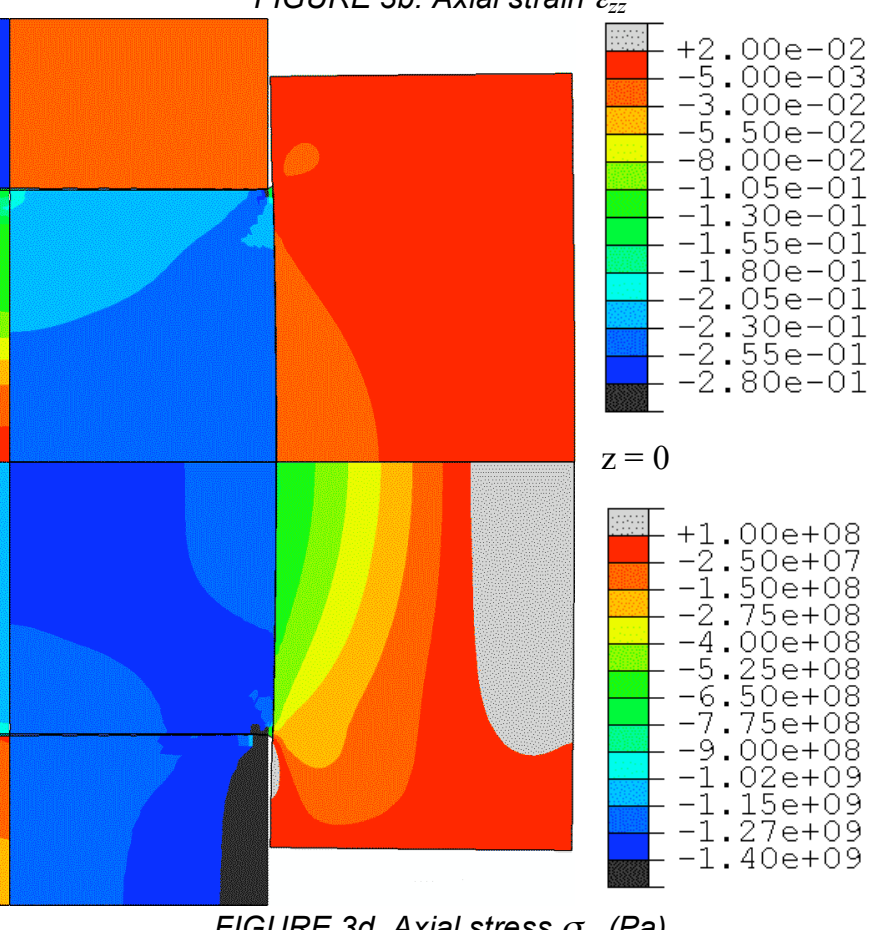

$\mathrm{z}=0$

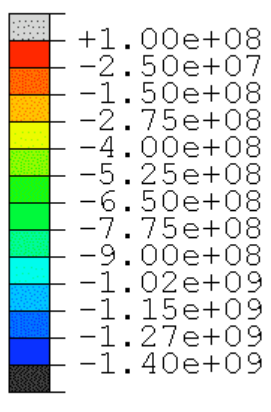

FIGURE 3d. Axial stress $\sigma_{z z}(\mathrm{~Pa})$

FIGURE 3. Numerical simulation of a 1D-strain compression test assuming a null friction. 
Discussion and validation of the methodology of processing the data

Figures 4, 5, 6 and 7 correspond to the processing of numerical simulations. For each following graph, the curve that corresponds to the imposed material behaviours according to Table 2 is compared with the curve obtained with the method that will be used to process experimental data (equations [1, 2, 3]). The result of the processing of the numerical simulation of Figure 3 is shown on Figure 4. No difference is observed between the "KST" curve (imposed material behaviour) and the curve from the processing of data. This very good agreement proves the quality of the processing method when there is no friction (satisfactory interpolation taking account of the specimen length). On the opposite, worse comparisons that are seen in Figures 5 show the effect of neglecting the axial contraction of the sample in equation [1] (Fig. 5a), or its radial swelling to evaluate the axial stress in equation [2] (Fig. 5b) or neglecting again the radial swelling to compute the volumetric strain in equation [6] (Fig. 5c).
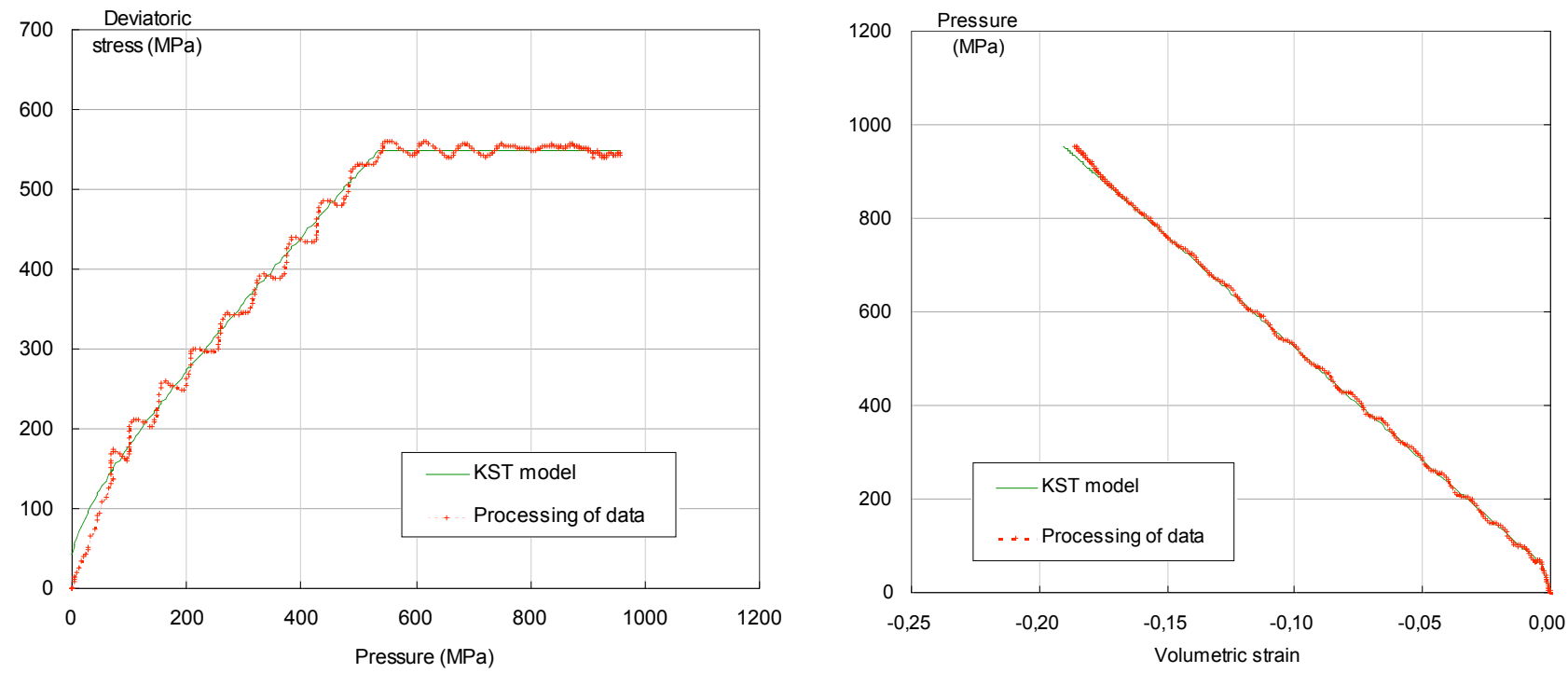

FIGURE. 4. Processing of data of the numerical simulation of Figure 3 (no friction between the specimen and the cell)
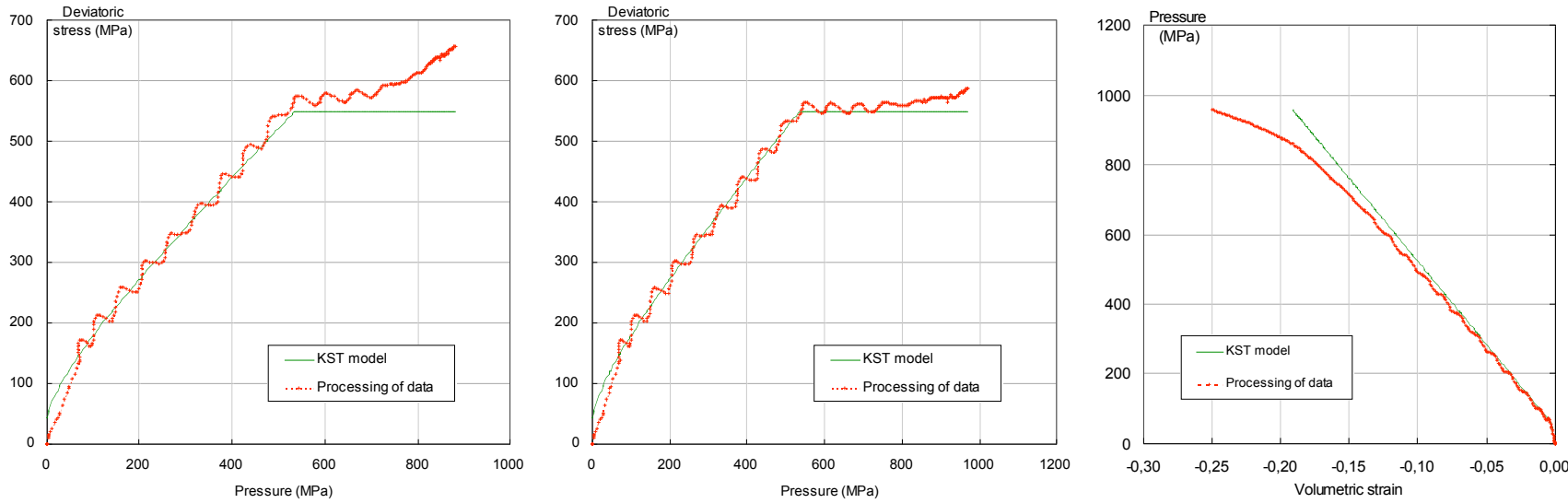

FIGURE 5a, left. The shortening of the specimen is neglected to compute the radial stress

FIGURE 5b, centre. The swelling of the specimen is neglected to compute the axial stress

FIGURE 5c, right. The swelling of the specimen is neglected to compute the volumetric strain

FIGURE 5. Illustration of possible uncompleted assumptions used in the processing of experimental data (based on the results of the numerical simulation of Figure 3 ) 
Influence of the friction on the precision of the analysis

In the calculations leading to Figure 6 , a coefficient of friction equal to 0.1 is used at the concrete sample/ring interface. The contact between the plug and the sample is assumed being without friction. In this case, one observes a maximum difference of deviatoric stress about $9 \%$ between the "KST" curve (imposed material behaviour) and the curve from the processing of data (Figure 6, left), which is definitely more important than without friction (Figure 4). It is also seen that the volumetric strain is underestimated at the end of the loading. Finally, the observed deviation on the volumetric strain is lower than approximately $5 \%$, up to a pressure of $900 \mathrm{MPa}$ (Figure 6, right). Figure 7 corresponds to the processing of a numerical simulation with a coefficient of friction equal to 0.1 at the concrete sample/plug interface. The contact between the ring and the sample is assumed being without friction. In that case, the deviation is seen to be as small as on Figure 4 . Therefore, friction at sample/plug interface appears without any influence on the processing of data.
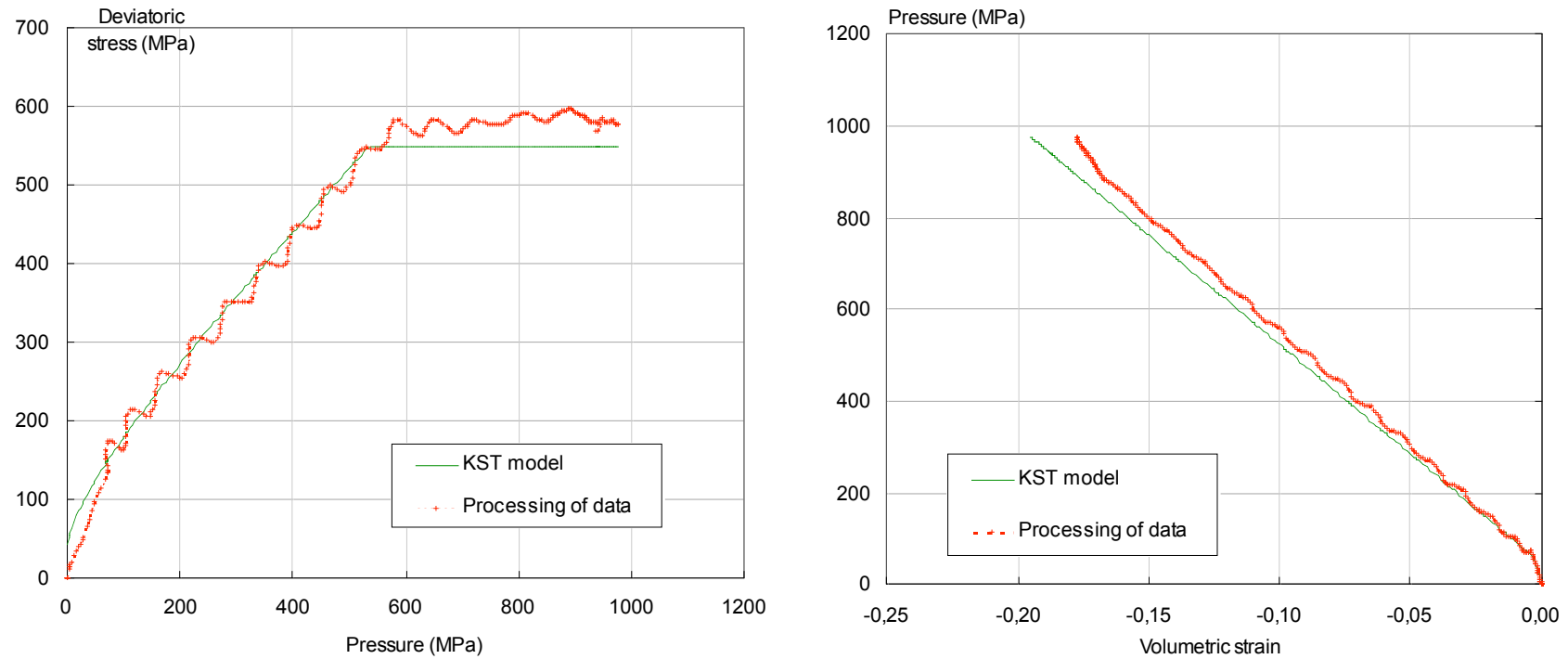

FIGURE 6. Processing of a numerical simulation of a test with friction between the specimen and the cell $(f=0.1)$
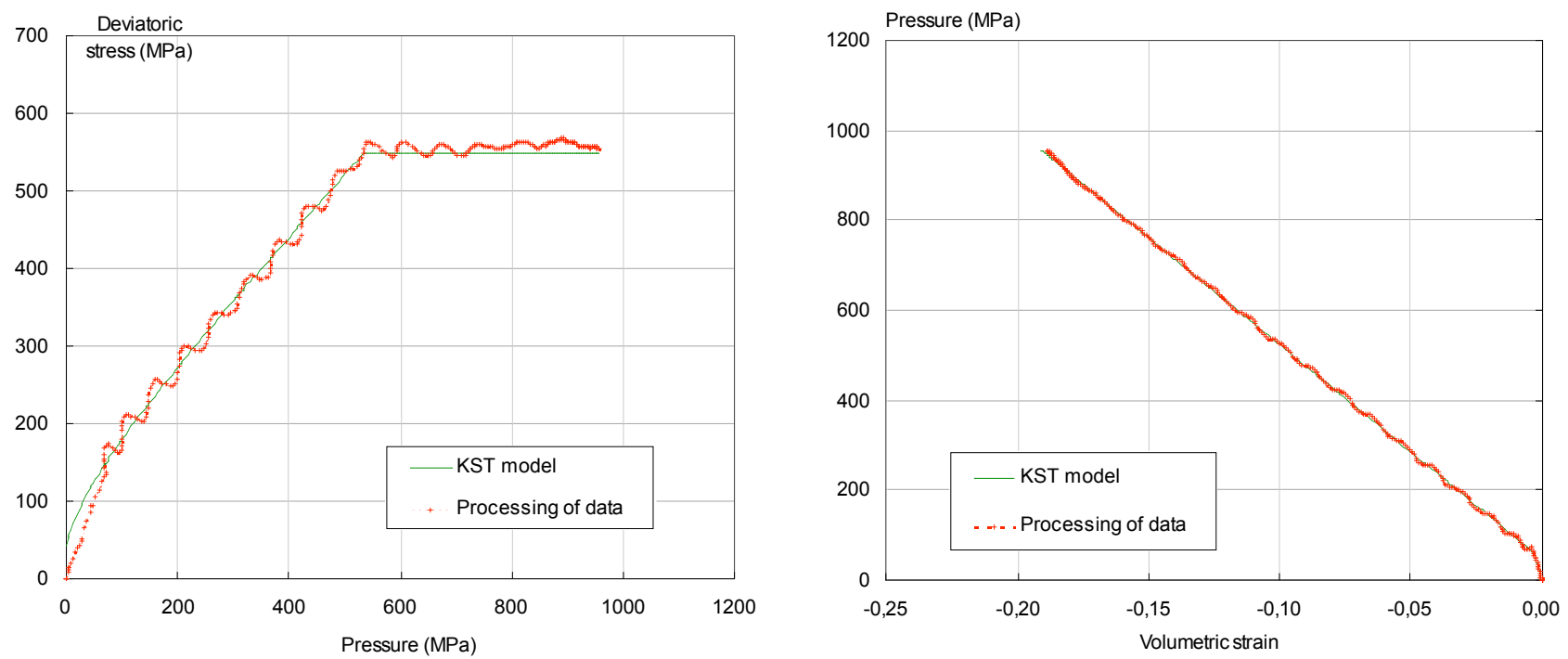

FIGURE 7. Processing of a numerical simulation of a test with friction between the plug and the specimen $(f=0.1)$

These numerical simulations allowed evaluating the quality and the robustness of the proposed processing method for 1Dstrain compression tests. It appears necessary to take into account the plastic strain of the confining cell when the inner 
pressure exceeds approximately $400 \mathrm{MPa}$. Moreover, as shown in the numerical simulations of the test, one also needs to take into account the sample shortening and its small radial expansion. The friction has a limited influence when the friction coefficient does not exceed 0.1 . To conclude, according to these numerical simulations, the deviation from real values of the deviatoric stress and of the volumetric strain due to the method will remain lower than $9 \%$ and $5 \%$, respectively.

\section{Dynamic behaviour of MB50 concrete}

Three dynamic 1D-strain compression tests were carried out with MB50 concrete samples (diameter: $30 \mathrm{~mm}$, height: $40 \mathrm{~mm}$ ) and with the confining cells described above. The assumption of a negligible friction between the cell and the specimen is specially addressed. The deviatoric behaviour (evolution of the deviatoric stress versus the hydrostatic pressure) and the spherical behaviour (evolution of the hydrostatic pressure versus volumetric strain) are computed.

Figure 8 shows the evolution of stresses and strains deduced from the processing of experimental data for one of the three $1 \mathrm{D}$-strain compression tests. This test was carried out at a mean strain rate equal to $221 \mathrm{~s}^{-1}$. The maximum value of strain rate reached during the test is equal to $415 \mathrm{~s}^{-1}$. The maximum hoop strain $\mathrm{G} 2$ was $0.2 \%$. Consequently, the cell had not a purely elastic behaviour, according to the numerical simulations of Figure 2. It is also observed that the loading can be divided into two phases (Figure 8a). Between 0 and $100 \mu \mathrm{s}$, the axial stress increases and the radial stress remains very low, like in a uniaxial compression test. Between 100 and $800 \mu \mathrm{s}$, the deviatoric stress and the hydrostatic pressure increase up to 1000 $\mathrm{MPa}$ and $900 \mathrm{MPa}$, respectively. The radial stress reaches $570 \mathrm{MPa}$ at the end of the test. The axial strain reaches the minimum value of $-19 \%$. The inner radial strain remains very small (Figure $8 \mathrm{~b}$ ). Consequently this test was close to a $1 \mathrm{D}$-strain compression test. The spherical and deviatoric behaviours corresponding to this test are shown on Figure 9 (curve "221 $\mathrm{s}^{-1}$ ").
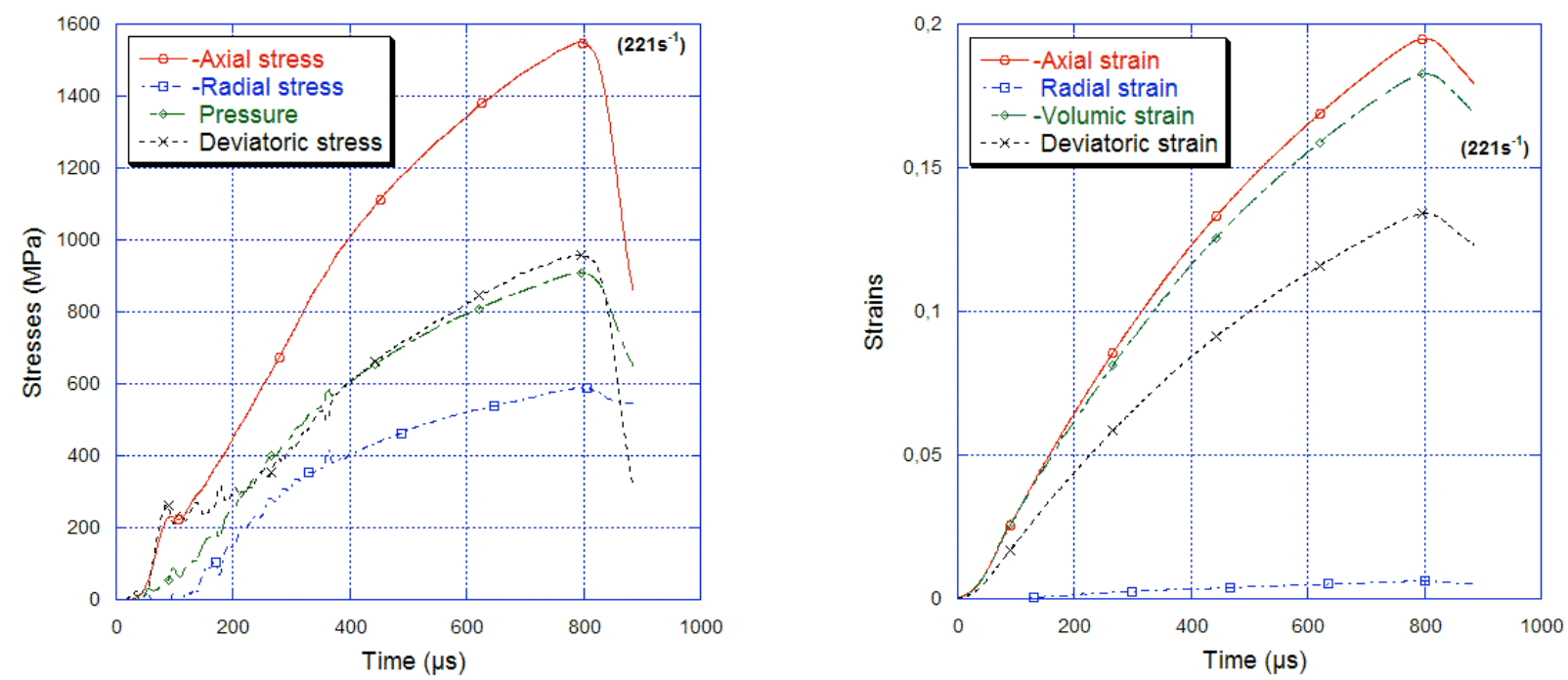

FIGURE 8a, left. Average stresses in the specimen (from processed data) FIGURE 8b, right. Average strains in the specimen (from processed data)

FIGURE 8. Evolution of stresses and strains for a 1D-strain compression test performed at $221 \mathrm{~s}^{-1}$. 

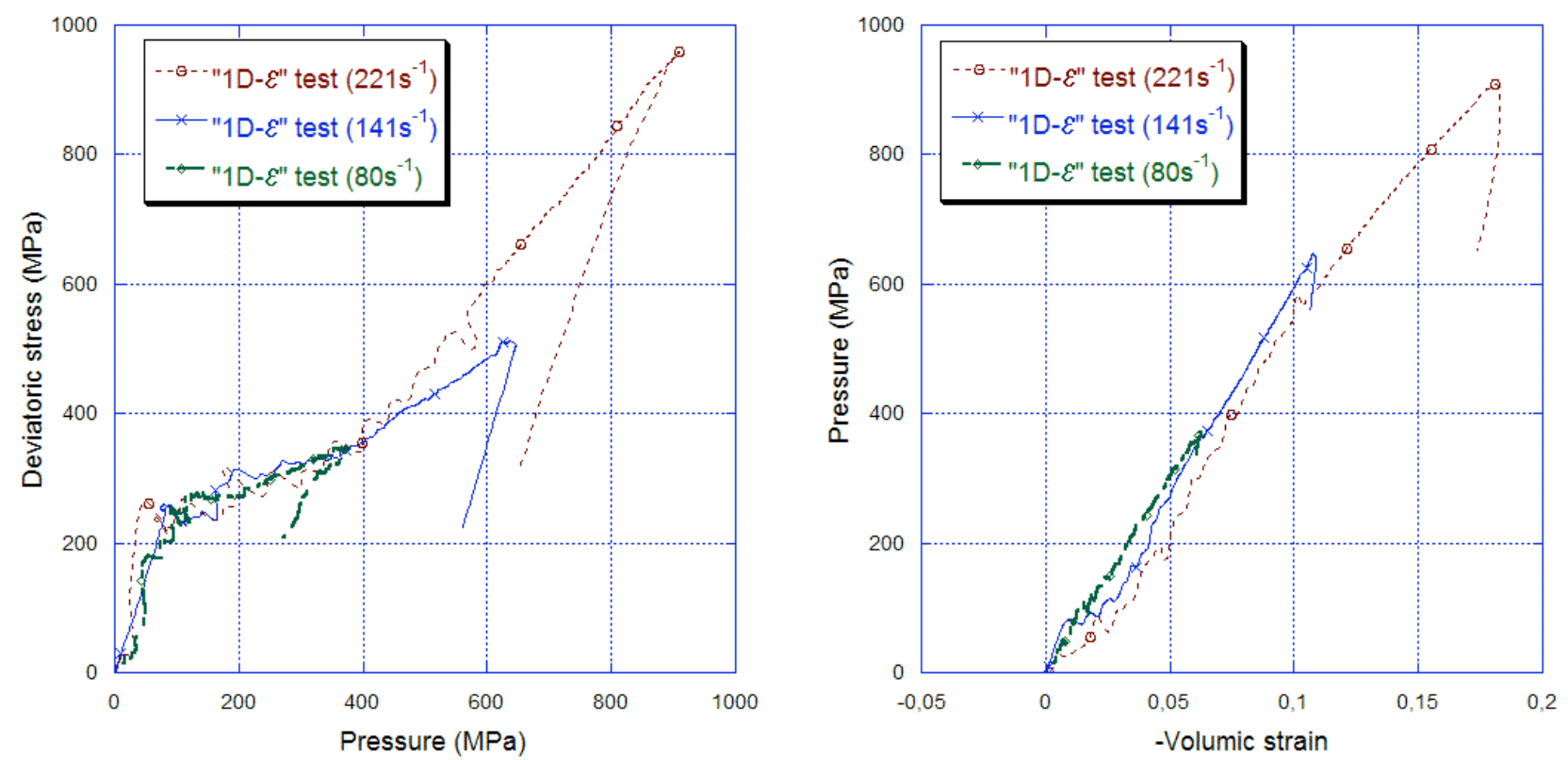

FIGURE 9. Behaviour of MB50 concrete deduced from three 1D-strain compression tests.

The three 1D-strain compression tests show that the deviatoric and spherical behaviours appear almost independent of the strain rate in the (rather narrow) observed range of strain rates (80-221 $\mathrm{s}^{-1}$, Figure 9). The deviatoric strength increases regularly with the hydrostatic pressure to reach $950 \mathrm{MPa}$ under a pressure of $900 \mathrm{MPa}$ (test "221 $\mathrm{s}^{-1 \text { ") }}$. Considering the spherical behaviour, an almost constant dynamic modulus of compressibility (around 5 to $6 \mathrm{GPa}$ ) is observed with the three 1D-strain compression tests up to a pressure of $900 \mathrm{MPa}$. It is smaller than the one deduced from purely hydrostatic compression tests ( 9 to $20 \mathrm{GPa}$ ) using a tri-axial cell (same concrete) [18] underlining a possible influence of the loading path or the strain rate on the response.

\section{Conclusions}

In this work, a testing device coupled to a new methodology of processing the experimental data were proposed allowing for the analysis of the mechanical behaviour of geomaterials under dynamic 1D-strain loading. This method leads to the knowledge of the deviatoric and spherical behaviours of the material tested. It is shown that as well the plastic behaviour of the cell as the shortening and the swelling of the specimen have to be taken into account in the analysis. Various numerical simulations of the test were carried out with the concrete plasticity model of Krieg, Swenson and Taylor. The method was applied successfully to artificial experimental data (free of noise) provided by those simulations. Moreover, a numerical simulation was carried out with a constant friction coefficient equal 0.1 . It proves a weak influence of friction (between the cell and the sample) on the computed response of the concrete behaviour. Three 1D-strain compression tests were performed and analysed with the proposed methodology of processing. They show that a high level of compaction strain (20\%) is available with this testing device. Stresses up to $1000 \mathrm{MPa}$, confinement pressures up to $600 \mathrm{MPa}$ and a strain rate range between 100 and $500 / \mathrm{s}$ can be achieved to suitably provide data to evaluate the dynamic behaviour of concrete and other rock-like materials under multiaxial dynamic loadings.

\section{References}

1. Gong J.C., Malvern L.E. and Jenkins D.A. Dispersion investigation in the split Hopkinson pressure bar, Journal of Engineering Material Technology 1990; 112:309-314.

2. Tang T., Malvern L.E. and Jenkins D.A., Rate effects in uniaxial dynamic compression of concrete, Journal of Engineering Mechanics 1992; 118:108-124.

3. Gary G. and Klepaczko J. R. Essai de compression dynamique sur béton, GRECO Geomaterial scientific report, 1992, pp.105-118.

4. Gary G. and Zhao H., Measurements of the dynamic behaviour of concrete under impact loading, In Chinese Journal Mechanics Press. Proceedings of 2nd ISIE'96. Beijing (China). 1996. p. 208-213. 
5. Malvern L.E., Jenkinds D.A., Tang T. \& McLure S. Dynamic testing of laterally confined concrete, In: Micromechanics of failure of quasi brittle materials, Elsevier Applied Science, 1991, 343-352.

6. Bertholf L.D., Karnes J. Two-dimensional analysis of the split Hopkinson pressure bar system, J. Mech. Phys. Solids 1975, 23:1-19.

7. Davies E.D.H., Hunter S.C. The dynamic compression testing of solids by the method of the split Hopkinson pressure bar. J. Mech. Phys. Solids 1963, 11:155-179.

8. Malinowski J. Z. and Klepaczko J. R. A unified analytic and numerical approach to specimen behaviour in split Hopkinson pressure bar system, Int J. Mech. Sci. 1986; 28: 381-391.

9. Gorham, D.A. Specimen inertia in high strain-rate compression. J.Phys D Appl.Phys 1989; 22:1888-1893.

10. Christensen R.J., Swansow S. R. and Brown W. S. Split Hopkinson bar test on rock under confining pressure. Experimental Mechanics $1972 ; 12: 508-541$.

11. Semblat J.F., Gary G. and Luong M.P., Dynamic response of sand using 3D Hopkinson bar, In: Proceedings of ISTOKYO'95 First International Conference on Earthquake Geotechnical Engineering, Tokyo (Japan), 1995.

12. Gary G., Bailly P., Behaviour of a quasi-brittle material at high strain rate. Experiment and modelling, European Journal of Mechanics 1998; 17(3):403-420.

13. Burlion N., Pijaudier-Cabot G. and Dahan N. Experimental analysis of compaction of concrete and mortar. Int. J. Numer. Anal. Meth. Geomec 2001; 25:467-1486.

14. Kolsky H. An investigation of mechanical properties of materials at very high rates of loading, Proceedings of the Physical Society London 1949; B 62:676-700.

15. Toutlemonde, F. Résistance au choc de structures en béton, PhD thesis, Ecole Nationale des Ponts et Chaussées, 1994.

16. Gatuingt, F. Prévision de la rupture des ouvrages en béton sollicités en dynamique rapide, PhD thesis, ENS Cachan, 1999.

17. Gatuingt F. and Pijaudier-Cabot G. Coupled damage and plasticity modelling in transient dynamic analysis of concrete. Int. J. Numer. Anal. Meth. Geomec. 2002 ; $26: 1--24$.

18. Buzaud, E. Performances mécaniques et balistiques du microbéton MB50. DGA/Centre d'Etudes de Gramat report 1998.

19. Hibitt H.D., Karlsson B.I., and Sorensen P. Abaqus User's manuel, ABAQUS/IMPLICIT 6.1 2001.

20. Forquin P., Arias A., Zaera R. An experimental method of measuring the confined compression strength of geomaterials. Int. J. Solids and Structures (Article in Press, Available on line) 2006.

21. Krieg R.D. A simple constitutive description for soils and crushable foams. Report, SC-DR-7260883, Sandia National Laboratory 1978.

22. Swenson D.V. and Taylor L.M. A finite element model for the analysis of tailored pulse stimulation of boreholes. Int. J. Num. Analyt. Meth. Geomech. 1983; 7:469-484.

23. Hibitt H.D., Karlsson B.I., and Sorensen P. Abaqus User's manuel, ABAQUS/EXPLICIT 6.12001. 